\title{
Dietary supplementation of dairy cows with a docosahexaenoic acid-rich thraustochytrid, Aurantiochytrium limacinum: effects on milk quality, fatty acid composition and cheese making properties
}

\author{
C.A. Moran ${ }^{1,4}$, M. Morlacchini' ${ }^{2}$ J.D. Keegan ${ }^{3}$, H. Warren ${ }^{3}$ and G. Fusconi ${ }^{2}$ \\ ${ }^{1}$ Alltech SARL, Rue Charles Amand, 14500 Vire, France \\ ${ }^{2}$ CERZOO Srl, Via Castellarino, San Bonico, 29122 Piacenza, Italy \\ ${ }^{3}$ Alltech European Bioscience Centre, Summerhill Road, Dunboyne, A86 X006 Ireland
}

KEY WORDS: milk quality, DHA, algae, supplements, cheese making, fatty acids, dairy cows

Received: 18 January 2018

Revised: 24 January 2019

Accepted: 11 March 2019

${ }^{4}$ Corresponding author:

e-mail: cmoran@alltech.com

\begin{abstract}
The aim of this study was to evaluate the effect of heterotrophically grown docosahexaenoic acid (DHA)-rich thraustochytrid Aurantiochytrium limacinum (AURA) added to dairy cow diet on milk fatty acid profile and milk cheese making properties. The secondary aim was to investigate the effect of pelleting on DHA transfer from diet to milk. Thirty six lactating dairy cows were blocked by parity, number of days in milk and by milk production and randomly assigned to 1 of 3 diets: AURA ( $150 \mathrm{~g} / \mathrm{cow} /$ day) with protein concentrate in pelleted or meal form, and control group - protein concentrate in pelleted form without AURA. Milk samples from each cow were taken on days $0,28,56$ and 84. Dietary supplementation for 84 days resulted in the successful enrichment of milk with DHA, at a level of 4.47 and $6.37 \mathrm{mg} / 100 \mathrm{ml}$ milk for the groups supplemented with AURA in a pelleted and meal form, respectively. As less DHA was detected in the pelleted concentrate ( $470 \mathrm{vs} 570 \mathrm{mg} / \mathrm{kg}$ ), and subsequently in the milk of the groups fed these pellets, the process of pelleting may have resulted in a loss of DHA from the feed. Dietary supplementation with AURA improved milk quality: increased DHA content and lowered n-6:n-3 ratio. With no differences observed for the cheese making properties of milk from cows fed supplemented or control diets, it can be stated that milk obtained from cows fed diet enriched with DHA-rich thraustochytrid Aurantiochytrium limacinum at a dose $150 \mathrm{~g} /$ cow/day (which gives about $24 \mathrm{~g}$ DHA/cow/day) can be suitable for cheese production.
\end{abstract}

\section{Introduction}

Polyunsaturated fatty acids (PUFA) are considered essential for general health and wellbeing (Gómez Candela et al., 2011), and may also play a role in limiting the effects of a number of chronic diseases (Ruxton et al., 2014). Omega-3 (n-3) and omega-6 (n-6) PUFA are both required to maintain good health; however, in many western countries n-3 fatty acid (FA) intake is below recommended levels, while n-6 PUFA intake is often considerably above recommended levels (Simopoulos, 2008). To address the lack of n-3 PUFA available in the food chain, dietary supplementation of intensively farmed animals with microalgae has been successfully used to increase the n-3 PUFA content in animal products (Moran et al., 2018a,b,c; 2019). For ruminants, the alteration of unsaturated fatty acids to form saturated fatty acids by ruminal microbes, via the processes of lipolysis and biohydro- 
genation, has made enrichment more difficult (Zymon et al., 2014). Despite these challenges, ruminant milk and meat have been successfully enriched (Papadopoulos et al., 2002; Moate et al., 2013; Moran et al., 2018b).

Few studies have investigated the effect of feeding dairy cows docosahexaenoic acid (DHA)-rich marine protists, such as microalgae or thraustochytrids, on the cheese making properties of milk. Dietary supplementation of cows with plant and fish oils, has been shown to enhance the PUFA content in milk and cheese without negatively affecting their consumer acceptability (Jones et al., 2005; Allred et al., 2006; Caroprese et al., 2013). Avramis et al. (2003) reported that cheddar cheese made from the milk of cows fed diets supplemented with fish meal ripened faster and developed a stronger flavour and texture. However, differences in casein micelle size and composition between the control and treatment groups, and a slower rate of firming when using the milk of cows fed fish meal supplemented diets, indicated potential difficulties in terms of cheese production.

Few studies have investigated the effect of pelleting on the bioavailability of DHA in dairy cows. A previous study on chickens indicated that pelleting does not affect the transfer of DHA into eggs (Moran et al., 2017a); however, the effect of pelleting on the transfer of DHA from the diet into milk remains to be evaluated.

So, the primary aim of this study was to evaluate the effect of enrichment of dairy cows diet with a heterotrophically grown DHA-rich thraustochytrid, Aurantiochytrium limacinum (AURA), on milk quality and its fatty acid profile, and milk cheese making properties. The secondary aim was to investigate the effect of pelleting on DHA transfer and bioavailability from diet.

\section{Material and methods}

\section{Animals, experimental design and diets}

The study was carried out at the CERZOO S.r.L. Research Centre (Piacenza, Italy) in compliance with G.L.P guidelines (Directives 2004/9/EC and 2004/10/ EC) for the collection, handling and documentation of data. The research protocol and animal care were carried out in accordance with European guidelines on the protection of animals used for scientific purposes (Directive 2010/63/EU). Cows were kept in six pens of six animals each on straw and chip litter bedding. Pens were cleaned and the bedding was renewed weekly. Animals were checked daily to ensure they were fit to take part in the trial and provided with free access to water. The cows were milked twice a day in a room with milking stalls equipped with Afimilk (Afimilk Ltd., Kibbutz Afikim, Israel) control panels which enabled individual identification of each cow facilitating the recording of production data.

Thirty-six lactating, Italian Friesian dairy cows [parity $2.3 \pm 1.3$; weight $672 \pm 73 \mathrm{~kg}$; days in milk (DIM) $164 \pm 65$; milk yield $39 \pm 8 \mathrm{~kg}$ ] were selected from those present on the farm to provide a group representative of various lactation stages. The cows were acclimatised to these conditions for a period of 10 days while under daily veterinary supervision to ensure they were fit to take part in the study. Prior to enrolment in the study, the cows were blocked by parity, number of DIM and milk production before being randomly assigned to 1 of 3 isonitrogenous and isoenergetic total mixed rations (TMR). Diets were formulated to meet or exceed the requirements of the average cow in the group according to the nutrient requirements of dairy cattle of National Reseach Council (NRC, 2001). The TMR contained maize silage $(26.0 \mathrm{~kg})$, protein concentrate $(4.9 \mathrm{~kg})$, hydrogenated palm oil $(0.32 \mathrm{~kg})$, maize and barley flake mix $(60: 40$ ratio, $1.5 \mathrm{~kg})$, maize and sorghum meal mix (80:20 ratio, $4.8 \mathrm{~kg})$, rye grass hay $(1.1 \mathrm{~kg})$, dehydrated alfalfa hay $(4.5 \mathrm{~kg})$ and water $(3.0 \mathrm{~kg})$. Minerals and vitamins were provided with the protein concentrate mixture. The protein concentrate composition for the control and treatment groups is shown in Table 1. The TMRs were supplemented through the protein concentrate, with $150 \mathrm{~g} / \mathrm{cow} /$ day of AURA provided

Table 1. Composition of the concentrates used in the preparation of the total mixed ration (TMR) for the control and Aurantiochytrium limacinum (AURA ${ }^{1}$ ) supplemented groups ( $\%$ dry matter, DM)

\begin{tabular}{lll}
\hline Concentrate composition & Control, \% DM & Treatment, \% DM \\
\hline Soybean meal & 44.34 & 44.43 \\
Sunflower dehulled meal & 18.5 & 18.0 \\
Corn gluten meal & 18.5 & 18.0 \\
Flaked soybeans & 6.0 & 6.0 \\
Sodium bicarbonate & 3.4 & 3.4 \\
Calcium carbonate & 3.4 & 3.4 \\
Hydrogenated palm oil fat & 2.16 & 0 \\
Magnesium oxide & 1.2 & 1.2 \\
Dicalcium phosphate & 0.8 & 0.8 \\
Sodium chloride & 0.8 & 0.8 \\
Premix & 0.8 & 0.8 \\
Zinc sulphate & 0.1 & 0.1 \\
AURA & 0 & 3.07
\end{tabular}

${ }^{1}$ AURA - unextracted Aurantiochytrium limacinum algae containing $17.04 \mathrm{~g} \mathrm{DHA} / 100 \mathrm{~g}$ (Alltech Inc., Nicholasville, KY, USA); ${ }^{2}$ each kg of premix contained: IU: vit. A 47640 , vit. $D_{3} 4368$; mg: vit. E 85.68, Ca 13.47, P 6.02, Mg 4.45, Na 12.65, Cu 47.35, Fe 261.16, Zn 135.90, I 1.55, Co 16.67, Mn 138.65, Se 0.47 
by Alltech Inc. (ALL-G-RICH ${ }^{\circledR}$, Nicholasville, KY, USA) and consisted of a heterotrophically grown, unextracted Aurantiochytrium limacinum (CCAP 4087/2) biomass for groups with AURA in a pelleted protein concentrate (APC) or AURA in a meal protein concentrate (AMC). These treated groups were compared to the control group with a pelleted protein concentrate (CPC). The protein concentrates for CPC, APC and AMC groups, were produced by a single mixing at Luigi Ferrari Feed mill (Sarmato, Piacenza, Italy), where the following conditions were adopted for the pelleted protein concentrate for CPC and APC groups production: vapour conditioning and pelleting (temperature $70-75^{\circ} \mathrm{C}$ ), pellet with diameter of $5 \mathrm{~mm}$ and length of $12-15 \mathrm{~mm}$.

The TMR was provided using one steel feeder per pen, with TMR intake recorded per pen and divided by the number of animals per pen to achieve an estimation of mean intake per cow. The composition of the three different TMRs was checked every 28 days. The TMRs were mixed in a Labrador 70 wagon (Storti, Belfiore, Verona, Italy), with the control TMR being mixed before the treatment TMRs to avoid cross-contamination. After the initial 10-day acclimatisation period, the groups were assigned and their feed and various productivity measurements were recorded over a period of 84 days. Intake of AURA was calculated based on the level of inclusion of the thraustochytrid in the treated protein concentrates $(3.07 \%)$ and the amount of protein concentrate in the TMR $(4.9 \mathrm{~kg} /$ cow $/$ day $=10.62 \%)$. The mean AURA intake for groups APC and AMC was then calculated using the mean TMR intake of each treated group for the entire period of the study that the algae was included in the feed (days 1-84).

\section{Sampling, measurements and analysis}

Fatty acid composition (method no. 996.06, AOAC International (2005); official method no. Ce 2c-11, AOCS (2017)) and crude fat content (method no. 954.02, AOAC International (2005)) of the AURA supplement were determined prior to the start of the study at Eurofins Scientific Inc. (Des Moines, IA, USA). Further analytical tests of the AURA supplement were performed at Chelab S.r.l, (Resana, Italy) using methods described in Regulation EC 152/2009 (Annex III): crude protein (Method C), crude fibre (Method I), moisture (Method A) and ash (Method M). In order to ensure the ration met the requirements of the trial animals, the nutrient composition of fresh TMR samples were analysed four times (every 28 days) using stan- dardised techniques: crude protein (ISO 5983-1), ADF (ISO 13906), NDF (ISO 16472), starch (ISO 10520:1997E), crude fat (ISO 6492), non-fibre carbohydrates - NFC; calculated according to equation: $100-[\mathrm{CP}+$ ash $+\mathrm{EE}+(\mathrm{NDF}-\mathrm{NDICP})]$, predicted metabolizable energy and net energy lactation (Gallo et al., 2013). Dry matter was calculated weekly by force drying TMR samples at $103{ }^{\circ} \mathrm{C}$ to a constant weight (ISO 6496). The DHA content of the concentrate and TMR samples was quantified (every 28 days) by direct fatty acid methyl ester synthesis according to O'Fallon et al. (2007), followed by quantification using the gas chromatography method described by Bannon et al. (1985).

\section{Health/Performance}

Live weight (LW) was recorded per cow, twice daily from day 0 to 84 and was calculated as the mean of the weights recorded automatically after milking. Individual milk production was also recorded from day 0 to 84 for each animal as the sum of the morning and afternoon milkings. Group TMR intake (dry matter basis) was calculated daily based on the total TMR offered per pen minus that refused. Body condition scores (BCS) were recorded on days 0 and 84 , by the same person using a score on a 0 to 5 scale, with one-point increments according to Agricultural Development and Advisory Service (ADAS, 1986). The rumination activity of all cows $(n=36)$ was recorded continuously using acoustic sensors (RuminACT, Milkline, Piacenza, Italy) for the entire 84-day treatment period, with data analysed at the Institute of Zootechnics, Catholic University of the Sacred Heart (Piacenza, Italy).

\section{Milk yield and composition}

Analysis of the milk was carried out for each cow on days $0,28,56$ and 84 . The milk sampling was carried out as follows: milk samples were taken from each cow in the morning and afternoon on two consecutive days; $5 \%$ of the milk production from each of the four milkings were then combined to generate a pool for each cow; the pool was then divided into three aliquots of at least $50 \mathrm{ml}$ each. For each cow, the first aliquot was used for the analysis of milk components (i.e. fat, protein, lactose, urea, somatic cell count). The second milk aliquot was used for the analysis of cheese making qualities (e.g., coagulant property, fermentative aptitude, natural creaming). Fat corrected milk (FCM, 4\%) was calculated as per Gaines and Davidson's formula (1923): FCM $(\mathrm{kg})=0.4 \mathrm{M}+15 \mathrm{~F}$ where: $\mathrm{M}-$ milk yield $(\mathrm{kg})$ and $\mathrm{F}-\mathrm{M} \times$ fat content (\%). 
The third aliquot was used to establish the milk fatty acid (FA) profile, by direct fatty acid methyl ester synthesis according to O'Fallon et al. (2007), followed by quantification using the gas chromatography method described by Bannon et al. (1985). DHA transfer efficiency from diet to milk was calculated as: DHA in milk yield $(\mathrm{g} / \mathrm{d}) /$ DHA intake $(\mathrm{g} / \mathrm{d}) \times 100$.

\section{Milk cheese making properties}

The cheese making qualities were established using the following methods:

- milk casein: Fourier transform mid-infrared spectroscopy (FT-MIR with Milkoscan FT-120; Foss Electric, Hillerød, Denmark);

- milk titratable acidity: MicroTT 2050 (Crison, Barcelona, Spain) automated titration system;

- milk fat natural creaming: method according to Speroni and Bertoni (1984);

- milk rennet coagulation: assessed as clotting time (r30), curd forming rate (k20) and curd firmness (a30) using the Formagraph (Foss Electric, Hillerød, Denmark) where $10 \mathrm{ml}$ milk was heated to $35^{\circ} \mathrm{C}$, and $200 \mu$ rennet (Hansen standard 190 with $63 \%$ chymosin and $37 \%$ pepsin; Pacovis rein, Bern, Switzerland) diluted to $1.6 \%(\mathrm{w} / \mathrm{w})$ in distilled water was added to milk.

\section{Statistical analysis}

For milk yield, LW, milk fatty acid profile and milk quality parameters the individual cow was the experimental unit. Results were checked for normality using the Shapiro-Wilk test and data were then analysed as repeated measures in a randomized design using the MIXED procedure of SAS (release 9.3, 2002-2010; SAS Institute Inc., Cary, NC, USA). Measured variables were subjected to two covariance structures: compound symmetry and autoregressive. The Akaike information criterion and the Schwarz Bayesian criterion were used to find out the covariance structures that best fit to the model for each parameter with significance being declared at $P \leq 0.05$. Data concerning milk parameters were also analysed using the General Linear Model (GLM) procedure of SAS. Tukey test was used to compare the means of each group. As the BCS data was not normally distributed the nonparametric Kruskal-Wallis test was used to establish the effect of AURA supplementation on BCS. Significant differences were indicated at $P \leq 0.05$. When significant differences were observed at day 0 , these values were used as a covariate in the overall analysis.

\section{Results}

\section{Ingredient and diet analysis}

The AURA used in the study contained $70.2 \mathrm{~g}$ of crude fat $/ 100 \mathrm{~g}$ dry matter (DM) biomass and $17.0 \mathrm{~g}$ DHA/100 g DM biomass with a significant amount of palmitic acid (36.0 g/100 g DM biomass). Additionally, the AURA contained $13.1 \%$ crude protein, $3.2 \%$ ash and $2.2 \%$ moisture. The nutrient composition of the TMR over the course of the experiment is summarised for the three groups (CPC, APC and AMC) in Table 2. Based on the mean pen TMR intake the estimated AURA intake for the APC and AMC groups was 142 and $144 \mathrm{~g} /$ cow/day, respectively, which would provide 24.14 and $24.48 \mathrm{~g}$

Table 2. Analytical composition (dry matter basis) (mean \pm S.D.) of control (CP) and Aurantiochytrium limacinum (AURA ${ }^{1}$ ) supplemented total mixed rations (TMR)

\begin{tabular}{|c|c|c|c|}
\hline Indices & $\begin{array}{l}\text { Control } \\
\text { pellet }\end{array}$ & $\begin{array}{l}\text { AURA } \\
\text { pellet }\end{array}$ & $\begin{array}{l}\text { AURA } \\
\text { meal }\end{array}$ \\
\hline Dry matter (DM), \% & $51.85 \pm 0.21$ & $51.66 \pm 0.24$ & $51.59 \pm 0.38$ \\
\hline Crude protein, \% DM & $15.43 \pm 0.01$ & $15.27 \pm 0.06$ & $15.28 \pm 0.18$ \\
\hline Fat, \% DM & $5.00 \pm 0.07$ & $4.97 \pm 0.10$ & $4.96 \pm 0.12$ \\
\hline $\begin{array}{l}\text { Non-fibre } \\
\text { carbohydrates, \% DM }\end{array}$ & $36.29 \pm 0.58$ & $36.37 \pm 0.42$ & $36.13 \pm 0.27$ \\
\hline ADF, $\%$ DM & $22.20 \pm 0.28$ & $22.69 \pm 0.17$ & $22.41 \pm 0.27$ \\
\hline NDF, \% DM & $37.25 \pm 0.52$ & $37.32 \pm 0.40$ & $37.48 \pm 0.15$ \\
\hline Starch, \% DM & $29.04 \pm 0.88$ & $29.22 \pm 0.45$ & $29.35 \pm 0.36$ \\
\hline Ash, \% DM & $6.08 \pm 0.14$ & $6.08 \pm 0.11$ & $6.15 \pm 0.10$ \\
\hline $\begin{array}{l}\text { Metabolizable energy, } \\
\text { Mcal/kg }\end{array}$ & $2.69 \pm 0.01$ & $2.69 \pm 0.01$ & $2.68 \pm 0.01$ \\
\hline $\begin{array}{l}\text { Net energy lactation, } \\
\text { Mcal/kg }\end{array}$ & $1.71 \pm 0.01$ & $1.70 \pm 0.01$ & $1.70 \pm 0.01$ \\
\hline $\begin{array}{l}\text { Docosahexaenoic } \\
\text { acid (DHA), mg/kg }\end{array}$ & 0 & $470 \pm 0.01$ & $570 \pm 0.01$ \\
\hline
\end{tabular}

${ }^{1}$ AURA - unextracted Aurantiochytrium limacinum containing $17.04 \mathrm{~g}$ DHA/100 g (Alltech Inc., Nicholasville, KY, USA)

DHA/cow/day. The mean DHA content detected in the TMR was 0.47 and $0.57 \mathrm{~g} / \mathrm{kg}$ for the APC and AMC groups, respectively. Based on the calculated TMR intake of the experimental groups, the mean estimated intake of DHA was 20.4 and $25.1 \mathrm{~g} / \mathrm{cow} /$ day for the APC and AMC groups, respectively.

\section{Animal productivity and milk parameters}

No differences in BCS, LW, rumen activity or milk yield (Table 3; Figure 1) were observed between the groups over the course of the study. Although there were no significant differences between the groups in terms of the milk SCC, a nu- 
Table 3. Performance indicators and milk quality parameters of cows fed total mixed rations (TMR) in the form of control pellet (CPC) or Aurantiochytrium limacinum (AURA ${ }^{1}$ ) supplemented pellet (APC) or meal (AMC) during an 84-day trial ${ }^{2}$

\begin{tabular}{|c|c|c|c|c|c|}
\hline Parameter & $\begin{array}{l}\text { Control } \\
\text { pellet }\end{array}$ & $\begin{array}{l}\text { AURA } \\
\text { pellet }\end{array}$ & $\begin{array}{l}\text { AURA } \\
\text { meal }\end{array}$ & S.E.M. ${ }^{8}$ & ${ }^{8} P$-value \\
\hline Body condition score ${ }^{3}$ & 2.36 & 2.35 & 2.34 & 0.10 & 0.99 \\
\hline TMR intake ${ }^{4,5}, \mathrm{~kg} \mathrm{DM}$ & 22.73 & 22.53 & 22.73 & 0.03 & 0.21 \\
\hline $\begin{array}{l}\text { Body weight (mean per } \\
\text { cow) }{ }^{6}, \mathrm{~kg}\end{array}$ & 663 & 663 & 668 & 21.57 & 0.99 \\
\hline $\begin{array}{l}\text { Rumination activity, min/ } \\
\text { cow/day }\end{array}$ & 486 & 456 & 443 & 18.65 & 0.27 \\
\hline Milk yield ${ }^{6}, \mathrm{~kg} /$ cow/day & 32.32 & 33.55 & 33.26 & 1.82 & 0.87 \\
\hline Milk fat content, $\%$ & 4.22 & 3.89 & 3.73 & 0.15 & 0.09 \\
\hline Milk fat production, kg/day & 1.30 & 1.28 & 1.22 & 0.06 & 0.58 \\
\hline Fat corrected milk, kg/day & 32.08 & 32.52 & 31.50 & 1.50 & 0.88 \\
\hline Protein content, \% & 3.47 & 3.39 & 3.38 & 0.07 & 0.67 \\
\hline Protein production, kg/day & 1.08 & 1.11 & 1.11 & 0.05 & 0.82 \\
\hline Lactose content, \% & 4.99 & 4.98 & 5.02 & 0.03 & 0.60 \\
\hline Lactose production, kg/day & 1.58 & 1.64 & 1.69 & 0.09 & 0.70 \\
\hline $\mathrm{SCC}^{7}, \times 10^{-3} \mathrm{CFU} / \mathrm{ml}$ & 198 & 346 & 205 & 87.40 & 0.41 \\
\hline Urea content, mg/dl & 23.20 & 21.20 & 21.60 & 0.91 & 0.27 \\
\hline
\end{tabular}

${ }^{1}$ AURA - unextracted Aurantiochytrium limacinum containing $17.04 \mathrm{~g}$ DHA/100 g (Alltech Inc., Nicholasville, KY, USA), so APC and AMC groups were supplemented with 20.1 and $25.1 \mathrm{~g}$ of DHA/cow/ day, respectively; ${ }^{2}$ twelve cows from each treatment group were sampled on four occasions (day 0, 28, 56 and 84) giving 48 milk samples per treatment group overall, with the data presented analysed as repeated measures; ${ }^{3}$ body condition score on day 84: 1 - emaciated; 2 - thin; 3 - moderate; 4 - stout; 5 - obese; ${ }^{4}$ mean of day 7-84, data analysed using an ANOVA with repeated measures; ${ }^{5}$ daily TMR intake (dry matter (DM) basis) per cow estimated from total TMR intake per pen/ number of cows per pen; ${ }^{6}$ mean of day 1-84 data analysed using an ANOVA with repeated measures; ${ }^{7}$ SCC - somatic cell counts; ${ }^{8}$ S.E.M. - standard error of the mean merically higher count was observed for the APC group due to consistently high values detected in the milk of a single cow at every time point $(1511,1253$, 1369 and $1650 \times 10^{3} \mathrm{CFU} / \mathrm{ml}$ on days $0,28,56$ and 84 , respectively). Near the end of the study a numerical increase in milk yield was observed for the treatment groups with the APC and AMC groups yielding up to $1.68 \mathrm{~kg}$ and $2.27 \mathrm{~kg}$, respectively, more milk than the CPC group. The fat content (\%) of the milk differed between the groups on day 56 with the AMC group having a significantly lower fat content than the CPC group (Table 4; $P=0.038$ ). A similar trend was evident in the repeated measures analysis for the entire study period in which the AMC group tended towards a lower fat content (\%) than the control $(P=0.087)$. No differences in FCM, protein, lactose or urea content were observed at any time point or over the course of the whole experiment.

\section{Milk fatty acid profile}

No DHA was detected in the milk of any of the groups at the beginning of the study and no DHA was detected in the milk of cows from the control group at any time point during the experiment. On each sampling day the AMC group has significantly more DHA ( $\mathrm{g} / 100 \mathrm{~g}$ fatty acids) than the APC and the CPC groups (Table 4). A similar pattern of enrichment over time was observed for both groups (Figure 2). Overall, the repeated measures analysis indicated that the mean DHA content of milk from the APC group was significantly higher than the control, while that from AM group was significantly higher than both other groups $(P<0.001)$. The level of EPA detected in the milk differed on day 28 , on

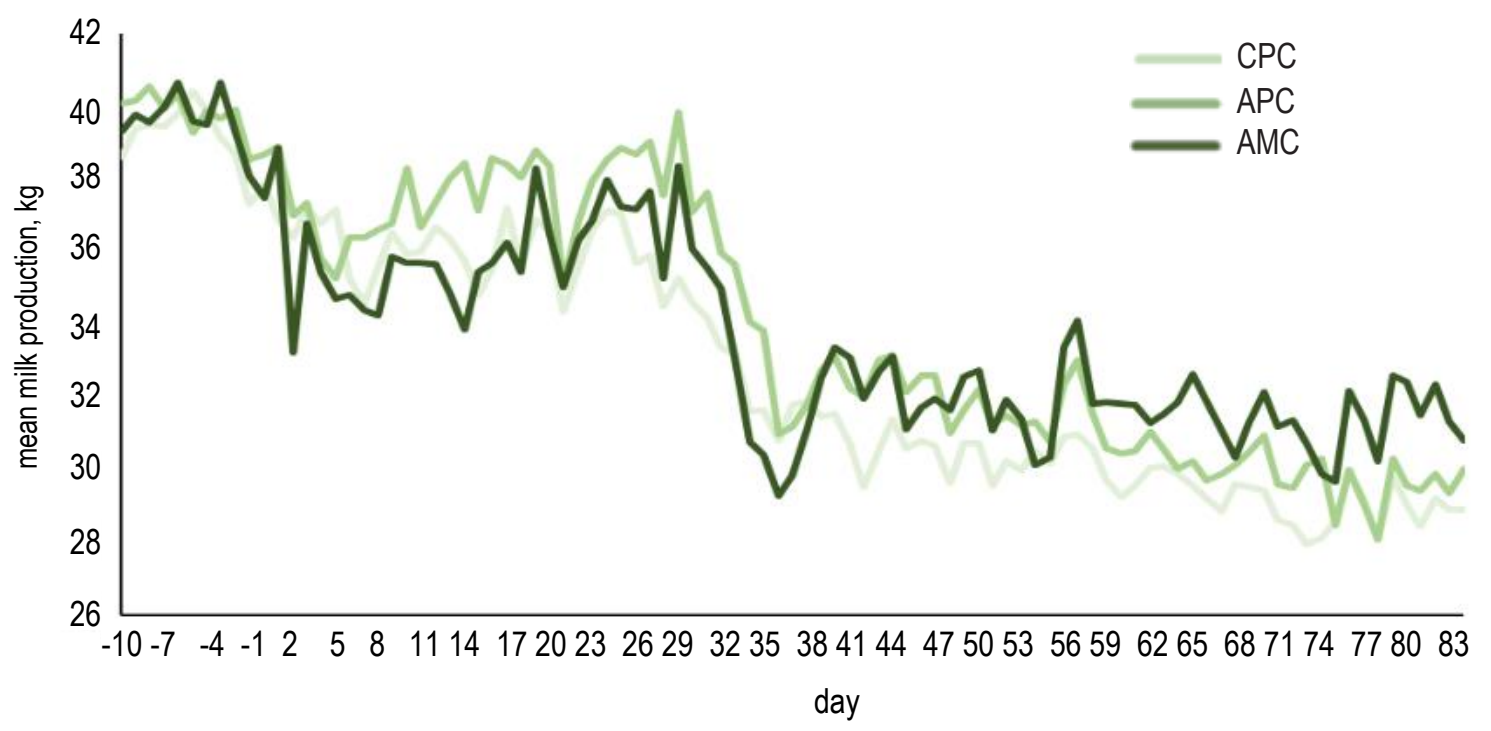

Figure 1. Milk yield (kg/day) from cows fed a control pellet (CPC) or docosahexaenoic acid (DHA)-rich microalgae Aurantiochytrium limacinum supplemented diet in either pellet (APC) or meal (AMC) form for an 84-day treatment period with a 10-day pre-treatment 


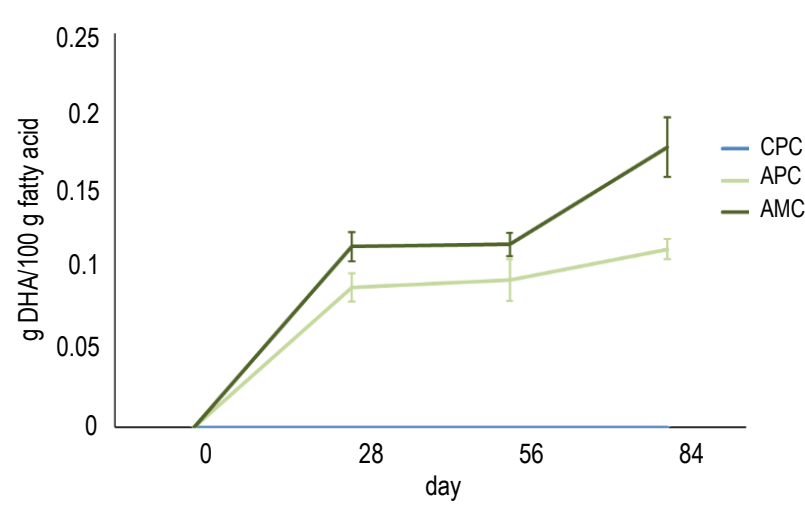

Figure 2. Milk docosahexaenoic acid (DHA) concentration ( $\mathrm{g} / 100 \mathrm{~g}$ fatty acids $\pm 95 \%$ C.I.) from cows fed a control diet (CPC) or diets supplemented with DHA-rich microalgae in pellet (APC) or meal (AMC) form

which the milk from the APC and AMC groups had significantly more EPA in the milk fat than the control group $(P=0.001)$, while on day 84 the AMC group has significantly more EPA than both other groups (Table 4). The n-6:n-3 ratio was the lowest for the AMC group, the difference being significant between AMC and both CPC and APC. The n-6:n-3 ratio was significantly lower for APC than for CPC $(P<0.0001$ in each case $)$. The results of the repeated measures analysis for the overall FA profiles of the experimental groups are shown in Table 5.

As TMR intake was recorded per pen and not per cow, the actual DHA intake of each animal could not be determined. The individual DHA intake was estimated based in the intake for the pen divided by the number of cows in the pen. Dietary supplementation for a period of 84 days with 20.5 and $25.1 \mathrm{~g} \mathrm{DHA} /$ cow/day resulted in 4.47 and $6.37 \mathrm{mg}$ DHA/100 ml milk, equating to 44.7 and $63.7 \mathrm{mg} / 1$ of milk, respectively for the APC and AMC groups. The estimated individual intake and mean concentration of DHA detected in the milk were used to calculate the efficiency of transfer of DHA from the feed to the milk using the following formula: DHA in milk ( $\mathrm{mg} / \mathrm{d}) /$ DHA intake $(\mathrm{mg} / \mathrm{d}) \times 100$. The transfer efficiencies calculated for each sampling day and overall are shown in Table 6.

\section{Milk cheese making qualities}

There were no differences between the control and treatment groups in terms of their milk casein content, milk fat natural creaming, or milk rennet coagulation properties at any time point or for the entire study period (Table 7). The difference between the groups in terms of milk titratable acidity showed tendency on day $28(P=0.1)$ with the AMC group having a lower value $\left(2.53^{\circ} \mathrm{SH} / 50 \mathrm{ml}\right)$ than the $\mathrm{CPC}$ and APC groups (2.84 and $2.80^{\circ} \mathrm{SH} / 50 \mathrm{ml}$, respectively).
Table 4. Milk production and composition parameters recorded for cows fed control pellet (CPC) or Aurantiochytrium limacinum (AURA') supplemented pellet (APC) or meal (AMC) at four time points over the course of the study ${ }^{2}$

\begin{tabular}{|c|c|c|c|c|c|}
\hline Indices & $\begin{array}{l}\text { Control } \\
\text { pellet }\end{array}$ & $\begin{array}{l}\text { AURA } \\
\text { pellet }\end{array}$ & $\begin{array}{l}\text { AURA } \\
\text { meal }\end{array}$ & S.E.M. ${ }^{3}$ & $P$-value \\
\hline \multicolumn{6}{|c|}{ Milk production, kg/cow/day } \\
\hline days $10-0$ & 39.08 & 39.72 & 39.43 & 2.291 & 0.980 \\
\hline days $1-28$ & 36.07 & 37.53 & 35.89 & 2.081 & 0.831 \\
\hline days $29-56$ & 31.34 & 33.02 & 32.36 & 1.878 & 0.818 \\
\hline days $57-84$ & 29.26 & 30.09 & 31.53 & 1.696 & 0.638 \\
\hline \multicolumn{6}{|l|}{ Milk fat, \% } \\
\hline day 0 & 3.92 & 3.96 & 3.96 & 0.157 & 0.980 \\
\hline day 28 & 4.09 & 3.69 & 3.67 & 0.176 & 0.185 \\
\hline day 56 & $4.15^{b}$ & $3.86^{\mathrm{ab}}$ & $3.54^{\mathrm{a}}$ & 0.161 & 0.038 \\
\hline day 84 & 4.42 & 4.14 & 3.98 & 0.171 & 0.196 \\
\hline \multicolumn{6}{|c|}{ Milk fat production } \\
\hline day 0 & 1.46 & 1.51 & 1.46 & 0.062 & 0.828 \\
\hline day 28 & 1.38 & 1.38 & 1.27 & 0.077 & 0.514 \\
\hline day 56 & 1.26 & 1.22 & 1.16 & 0.057 & 0.488 \\
\hline day 84 & 1.26 & 1.24 & 1.21 & 0.066 & 0.881 \\
\hline \multicolumn{6}{|c|}{ Milk protein content, $\%$} \\
\hline day 0 & 3.37 & 3.35 & 3.35 & 0.084 & 0.986 \\
\hline day 28 & 3.37 & 3.28 & 3.26 & 0.076 & 0.567 \\
\hline day 56 & 3.46 & 3.42 & 3.36 & 0.076 & 0.633 \\
\hline day 84 & 3.57 & 3.47 & 3.53 & 0.082 & 0.696 \\
\hline \multicolumn{6}{|c|}{ Milk protein production, $\mathrm{kg} /$ day } \\
\hline day 0 & 1.26 & 1.28 & 1.24 & 0.050 & 0.874 \\
\hline day 28 & 1.15 & 1.22 & 1.14 & 0.056 & 0.538 \\
\hline day 56 & 1.06 & 1.09 & 1.11 & 0.051 & 0.768 \\
\hline day 84 & 1.02 & 1.03 & 1.07 & 0.045 & 0.696 \\
\hline \multicolumn{6}{|c|}{$\mathrm{EPA}^{4}, \%$ of total fatty acids } \\
\hline day 0 & 0.03 & 0.03 & 0.03 & 0.002 & 0.788 \\
\hline day 28 & $0.029^{b}$ & $0.035^{\mathrm{a}}$ & $0.034^{a}$ & 0.001 & 0.001 \\
\hline day 56 & 0.03 & 0.03 & 0.03 & 0.001 & 0.086 \\
\hline day 84 & $0.031^{b}$ & $0.034^{b}$ & $0.042^{\mathrm{a}}$ & 0.002 & 0.001 \\
\hline \multicolumn{6}{|c|}{$\mathrm{DHA}^{5}, \%$ of total fatty acids } \\
\hline day 0 & 0.00 & 0.00 & 0.00 & - & - \\
\hline day 28 & $0.00^{c}$ & $0.09^{b}$ & $0.11^{\mathrm{a}}$ & 0.004 & $<0.001$ \\
\hline day 56 & $0.00^{c}$ & $0.09^{b}$ & $0.12^{\mathrm{a}}$ & 0.004 & $<0.001$ \\
\hline day 84 & $0.00^{c}$ & $0.11^{\mathrm{b}}$ & $0.18^{\mathrm{a}}$ & 0.006 & $<0.001$ \\
\hline \multicolumn{6}{|l|}{$n-6: n-3$ ratio } \\
\hline day 0 & 3.94 & 3.99 & 4.02 & 0.063 & 0.705 \\
\hline day 28 & $4.30^{\mathrm{a}}$ & $3.95^{b}$ & $3.67^{c}$ & 0.071 & $<0.001$ \\
\hline day 56 & $4.06^{\mathrm{a}}$ & $3.74^{b}$ & $3.60^{c}$ & 0.043 & $<0.001$ \\
\hline day 84 & $4.26^{\mathrm{a}}$ & $3.64^{b}$ & $3.38^{c}$ & 0.049 & $<0.001$ \\
\hline
\end{tabular}

${ }^{1}$ AURA - unextracted Aurantiochytrium limacinum containing $17.04 \mathrm{~g}$ DHA/100 g (Alltech Inc., Nicholasville, KY, USA), so APC and AMC groups were supplemented with $20.1 \mathrm{~g}$ and $25.1 \mathrm{~g}$ of DHA/cow/day, respectively; ${ }^{2}$ twelve cows from each treatment group were sampled on four occasions: day $0,28,56$ and $84 ;{ }^{3}$ S.E.M. - standard error of the mean; ${ }^{4}$ EPA - eicosapentaenoic acid; ${ }^{5} \mathrm{DHA}$ - docosahexaenoic acid; ${ }^{a b c}$ - means within a row with different superscripts are significantly different 
Table 5. Repeated measures analysis of the milk fatty acid composition ( $\mathrm{g} / 100 \mathrm{~g}$ of fatty acids) for cows fed control pellet (CP) or Aurantiochytrium limacinum (AURA') supplemented pellet (APC) or meal (AMC) for 84 days ${ }^{2}$

\begin{tabular}{|c|c|c|c|c|c|}
\hline Fatty acid & Control pellet & $\begin{array}{l}\text { AURA } \\
\text { pellet }\end{array}$ & $\begin{array}{l}\text { AURA } \\
\text { meal }\end{array}$ & S.E.M $M^{3}$ & $P$-value \\
\hline Butyric acid (C4:0) & 1.74 & 1.76 & 1.73 & 0.041 & 0.907 \\
\hline Caproic acid (C6:0) & 1.69 & 1.64 & 1.65 & 0.044 & 0.716 \\
\hline Caprylic acid (C8:0) & 1.18 & 1.14 & 1.17 & 0.036 & 0.633 \\
\hline Capric acid (C10:0) & 2.84 & 2.71 & 2.83 & 0.107 & 0.651 \\
\hline Undecanoic acid (C11:0) & 0.07 & 0.06 & 0.05 & 0.006 & 0.173 \\
\hline Lauric acid (C12:0) & 3.42 & 3.23 & 3.43 & 0.130 & 0.493 \\
\hline Tridecanoic acid (C13:0) & 0.11 & 0.10 & 0.10 & 0.004 & 0.321 \\
\hline Myristic acid (C14:0) & 11.94 & 11.74 & 12.19 & 0.242 & 0.431 \\
\hline Myristoleic acid (C14:1) & $1.12^{\mathrm{ab}}$ & $1.06^{b}$ & $1.29^{a}$ & 0.060 & 0.031 \\
\hline Pentadecanoic acid (C15:0) & 1.06 & 1.05 & 1.03 & 0.027 & 0.677 \\
\hline Palmitic acid $(\mathrm{C} 16: 0)$ & 37.44 & 38.02 & 37.22 & 0.666 & 0.679 \\
\hline Palmitoleic acid (C16:1) & 1.97 & 2.14 & 2.23 & 0.083 & 0.102 \\
\hline Heptadecanoic acid (C17:0) & 0.47 & 0.47 & 0.46 & 0.010 & 0.831 \\
\hline cis-10-heptadecenoic acid (C17:1) & 0.04 & 0.04 & 0.04 & 0.002 & 0.290 \\
\hline Stearic acid $(\mathrm{C} 18: 0)$ & $9.99^{a}$ & $8.87^{\mathrm{b}}$ & $8.55^{b}$ & 0.307 & 0.006 \\
\hline Vaccenic acid (C18:1n9trans) & $1.77^{\mathrm{b}}$ & $2.75^{\mathrm{a}}$ & $2.85^{\mathrm{a}}$ & 0.192 & 0.005 \\
\hline Oleic acid (C18:1n9cis) & 20.00 & 19.56 & 19.41 & 0.599 & 0.771 \\
\hline C18:1n11cis & $0.28^{b}$ & $0.35^{\mathrm{a}}$ & $0.35^{\mathrm{ab}}$ & 0.019 & 0.033 \\
\hline Linoleic acid (C18:2n6cis) & 1.71 & 1.82 & 1.89 & 0.058 & 0.103 \\
\hline Rumenic acid (C18:2) & $0.39^{b}$ & $0.64^{a}$ & $0.67^{a}$ & 0.037 & $<0.001$ \\
\hline a-Linolenic acid (C18:3n3) & 0.26 & 0.27 & 0.28 & 0.010 & 0.344 \\
\hline Y-Linolenic acid (C18:3n6) & 0.04 & 0.03 & 0.03 & 0.001 & 0.074 \\
\hline Arachidic acid (C20:0) & 0.11 & 0.12 & 0.11 & 0.003 & 0.589 \\
\hline cis-11,14,17-Eicosatrienoic acid (C20:3n3) & $0.15^{\mathrm{a}}$ & $0.11^{\mathrm{b}}$ & $0.11^{b}$ & 0.004 & $<0.001$ \\
\hline cis-8,11,14-Eicosatrienoic acid (C20:3n6) & $0.11^{\mathrm{a}}$ & $0.08^{b}$ & $0.08^{b}$ & 0.004 & $<0.001$ \\
\hline Eicosapentaenoic acid (C20:5n3) (EPA) & $0.03^{b}$ & $0.03^{\mathrm{a}}$ & $0.04^{\mathrm{a}}$ & 0.001 & 0.001 \\
\hline Behenic acid (C22:0) & $0.03^{b}$ & $0.06^{\mathrm{a}}$ & $0.06^{\mathrm{a}}$ & 0.002 & 0.003 \\
\hline Docosahexaenoic acid (C22:6n3) (DHA) & $0.00^{\circ}$ & $0.10^{\mathrm{b}}$ & $0.14^{\mathrm{a}}$ & 0.004 & $<0.001$ \\
\hline Lignoceric acid (C24:0) & 0.03 & 0.03 & 0.03 & 0.001 & 0.002 \\
\hline$\Sigma$ Short-chain fatty acids ${ }^{4}$ & 4.62 & 4.53 & 4.54 & 0.111 & 0.850 \\
\hline$\Sigma$ Medium-chain fatty acids ${ }^{4}$ & 20.56 & 19.96 & 20.91 & 0.465 & 0.354 \\
\hline$\Sigma$ Long-chain fatty acids ${ }^{4}$ & 74.83 & 75.51 & 74.54 & 0.520 & 0.414 \\
\hline$\Sigma$ Saturated fatty acid & 72.13 & 71.00 & 70.60 & 0.706 & 0.297 \\
\hline$\Sigma$ Unsaturated fatty acid & 27.87 & 29.00 & 29.40 & 0.706 & 0.297 \\
\hline$\Sigma$ Monounsaturated fatty acid & 25.17 & 25.91 & 26.16 & 0.648 & 0.540 \\
\hline$\Sigma$ Polyunsaturated fatty acid (PUFA) & $2.70^{\mathrm{b}}$ & $3.09^{\mathrm{a}}$ & $3.24^{\mathrm{a}}$ & 0.095 & 0.001 \\
\hline n-3 PUFA 5 & $0.44^{c}$ & $0.51^{b}$ & $0.57^{\mathrm{a}}$ & 0.014 & $<0.001$ \\
\hline n-6 PUFA ${ }^{6}$ & 1.87 & 1.94 & 2.01 & 0.059 & 0.247 \\
\hline$n-6: n-3$ & $4.21^{\mathrm{a}}$ & $3.78^{b}$ & $3.55^{c}$ & 0.046 & $<0.001$ \\
\hline
\end{tabular}

${ }^{1}$ AURA - unextracted Aurantiochytrium limacinum containing $17.04 \mathrm{~g} \mathrm{DHA} 100 \mathrm{~g}$ (Alltech Inc., Nicholasville, KY, USA), so APC and AMC groups were supplemented with 20.1 and $25.1 \mathrm{~g}$ of DHA/cow/day, respectively; ${ }^{2}$ twelve cows from each treatment group were sampled on four occasions (day 0,28, 56 and 84 ) giving 48 milk samples per treatment group overall, with the data presented analysed as repeated measures; ${ }^{3}$ S.E.M. - standard error of the mean; ${ }^{4}$ the complete fatty acid profile included: short-chain fatty acids (from C4:0 to C8:0), medium-chain fatty acids (from $\mathrm{C} 10: 0$ to $\mathrm{C} 15: 1$ ) and long-chain fatty acids (from $\mathrm{C} 16: 0$ to $\mathrm{C} 22: 6 \mathrm{n} 3$ ); ${ }^{5}$ the total $n-3$ PUFA composition was calculated as the $\Sigma$ [a-linolenic acid (C18:3n3) + cis-11,14,17-eicosatrienoic acid (C20:3n3) + EPA (C20:5n3) + DHA (C22:6n3)]; ${ }^{6}$ the total n-6 PUFA composition was calculated as the $\sum$ [linolelaidic acid (C18:2n6trans) + linoleic acid (C18:2n6cis) + y-linolenic acid (C18:3n6) + cis-8,11,14-eicosatrienoic acid $(\mathrm{C} 20: 3 n 6)+$ arachidonic acid $(\mathrm{C} 20: 4 n 6)]$; abc - means within a row with different superscripts are significantly different 
Table 6. Estimated transfer efficiency (\%) of docosahexaenoic acid (DHA) to milk from feeding either an Aurantiochytrium limacinum (AURA ${ }^{1}$ ) supplemented pellet (APC) or meal (AMC) to dairy cows as part of their total mixed ration (TMR) for an 84-day trial2

\begin{tabular}{|c|c|c|c|c|c|c|c|c|c|c|}
\hline Group & Day & $\begin{array}{l}\text { DHA in milk', } \\
\text { g/100 g } \\
\text { fatty acids }\end{array}$ & $\begin{array}{l}\text { Milk production }{ }^{1} \text {, } \\
\text { kg/day }\end{array}$ & $\begin{array}{l}\text { Milk fat }{ }^{1} \text {, } \\
100 \text { g/day }\end{array}$ & $\begin{array}{l}\text { Mean DHA } \\
\text { in milk } \text { k }^{3}, \mathrm{mg} / \mathrm{d}\end{array}$ & $\begin{array}{l}\text { Mean DHA in } \\
\text { milk4 }^{4}, \mathrm{mg} / 100 \\
\mathrm{ml}\end{array}$ & $\begin{array}{l}\text { Estimated } \\
\text { TMR intake } \\
\text { kg/cow/day }\end{array}$ & $\begin{array}{l}\text { TMR DHA } \\
\text { content } 6 \text {, } \\
\text { mg/kg }\end{array}$ & $\begin{array}{l}\text { Estimated } \\
\text { DHA intake }{ }^{7} \text {, } \\
\text { mg/cow/day }\end{array}$ & $\begin{array}{l}\text { Estimated } \\
\text { transfer } \\
\text { efficiency }^{8}, \%\end{array}$ \\
\hline \multirow{4}{*}{$\begin{array}{l}\text { AURA } \\
\text { pellet }\end{array}$} & 28 & 0.089 & 37.53 & 13.8 & 1143 & 3.05 & 44.58 & 470 & 20953 & 5.46 \\
\hline & 56 & 0.094 & 33.02 & 12.2 & 1065 & 3.23 & 44.94 & 450 & 19841 & 5.47 \\
\hline & 84 & 0.113 & 29.26 & 12.4 & 1308 & 4.47 & 43.29 & 470 & 20229 & 6.47 \\
\hline & $7-84$ & 0.099 & 32.32 & 12.8 & 1176 & 3.64 & 43.55 & 470 & 20497 & 5.74 \\
\hline \multirow{4}{*}{$\begin{array}{l}\text { AURA } \\
\text { meal }\end{array}$} & 28 & 0.115 & 35.89 & 12.7 & 1359 & 3.79 & 43.04 & 580 & 26065 & 5.21 \\
\hline & 56 & 0.116 & 32.36 & 11.6 & 1257 & 3.88 & 43.74 & 560 & 24388 & 5.15 \\
\hline & 84 & 0.178 & 31.35 & 12.1 & 2007 & 6.37 & 43.61 & 570 & 24392 & 8.05 \\
\hline & $7-84$ & 0.136 & 32.36 & 12.2 & 1550 & 4.81 & 44.06 & 570 & 25114 & 6.17 \\
\hline
\end{tabular}

${ }^{1}$ AURA - unextracted Aurantiochytrium limacinum containing $17.04 \mathrm{~g}$ DHA/100 g (Alltech Inc., Nicholasville, KY, USA), so APC and AMC groups were supplemented with 20.1 and $25.1 \mathrm{~g}$ of DHA/cow/day, respectively; ${ }^{2}$ twelve cows from each treatment group were sampled on four occasions (day 0, 28, 56 and 84) giving 48 milk samples per treatment group overall; ${ }^{3}$ mean DHA content in milk (mg/day) was calculated using the following formula: $(0.933 \times$ milk fat $(100 \mathrm{~g} /$ day $) \times \mathrm{DHA}$ (mg/100 g fatty acid) $\times 1000$ (Glasser et al., 2007) in fact, the proportion of fatty acyl radicals (i.e., FA from which the $\mathrm{OH}$ group has been removed; ${ }^{4}$ mean DHA in milk (mg/100 ml) calculated as (mean DHA in milk (mg/day) / milk production (kg/day)) / 10; ${ }^{5}$ TMR intake (as fed) recorded per pen and divided by the number of animals per pen to achieve an estimation of mean intake per cow; ${ }^{6} \mathrm{DHA}$ concentration of the TMR for the preceding 28 -day period; ${ }^{7}$ estimated TMR content $=$ estimated TMR intake $(\mathrm{kg} / \mathrm{cow} /$ day $) \times$ TMR DHA content (mg/kg); ${ }^{8}$ estimated transfer efficiency (\%) of DHA from diet to milk = DHA in milk (mg/day) $/$ DHA intake $(\mathrm{mg} /$ day) $\times 100$

Table 7. Cheese making qualities of milk from cows fed control pellet (CPC) or Aurantiochytrium limacinum (AURA') supplemented pellet (APC) or meal (AMC) for the duration of 84 days $^{2}$

\begin{tabular}{|c|c|c|c|c|c|c|c|c|c|c|c|}
\hline $\begin{array}{l}\text { Days from } \\
\text { the start of } \\
\text { the study }\end{array}$ & $\begin{array}{l}\text { Control } \\
\text { pellet }\end{array}$ & $\begin{array}{l}\text { AURA } \\
\text { pellet }\end{array}$ & $\begin{array}{l}\text { AURA } \\
\text { meal }\end{array}$ & S.E.M. ${ }^{3}$ & $\begin{array}{l}\text { Treatment } \\
\text { effect } \\
P \text {-value }\end{array}$ & $\begin{array}{l}\text { Days from } \\
\text { the start of } \\
\text { the study }\end{array}$ & $\begin{array}{l}\text { Control } \\
\text { pellet }\end{array}$ & $\begin{array}{l}\text { AURA } \\
\text { pellet }\end{array}$ & $\begin{array}{l}\text { AURA } \\
\text { meal }\end{array}$ & S.E.M. ${ }^{3}$ & $\begin{array}{l}\text { Treatment } \\
\text { effect } \\
P \text {-value }\end{array}$ \\
\hline \multicolumn{6}{|c|}{ Milk casein, \% } & \multicolumn{6}{|c|}{ Milk rennet: clotting time (r30) } \\
\hline day 0 & 2.61 & 2.58 & 2.61 & 0.06 & 0.90 & day 0 & 22.23 & 20.36 & 19.40 & $1.70^{*}$ & 0.50 \\
\hline day 28 & 2.53 & 2.44 & 2.45 & 0.05 & 0.41 & day 28 & 22.74 & 21.03 & 22.20 & $1.88^{*}$ & 0.80 \\
\hline day 56 & 2.61 & 2.54 & 2.57 & $0.05^{*}$ & 0.60 & day 56 & 22.19 & 24.41 & 25.39 & 1.97 & 0.51 \\
\hline day 84 & 2.74 & 2.65 & 2.68 & 0.06 & 0.60 & day 84 & 22.24 & 24.52 & 25.16 & $1.81^{*}$ & 0.53 \\
\hline days $7-84^{4}$ & 2.63 & 2.54 & 2.57 & $0.05^{*}$ & 0.40 & days $7-84^{4}$ & 22.39 & 23.32 & 24.25 & $1.17^{*}$ & 0.50 \\
\hline \multicolumn{6}{|c|}{ Milk titratable acidity, SH/50 ml } & \multicolumn{6}{|c|}{ Milk rennet: curd firming time (k20) } \\
\hline day 0 & 3.44 & 3.37 & 3.22 & 0.11 & 0.40 & day 0 & 7.10 & 7.74 & 8.07 & $0.63^{*}$ & 0.55 \\
\hline day 28 & 2.84 & 2.80 & 2.53 & 0.11 & 0.10 & day 28 & 7.80 & 7.13 & 8.26 & $0.77^{*}$ & 0.59 \\
\hline day 56 & 3.16 & 3.07 & 3.04 & $0.14^{*}$ & 0.82 & day 56 & 7.24 & 8.19 & 8.47 & 0.95 & 0.63 \\
\hline day 84 & 3.13 & 2.99 & 2.98 & 0.12 & 0.57 & day 84 & 7.15 & 7.34 & 8.45 & $0.73^{*}$ & 0.42 \\
\hline days $7-84^{4}$ & 3.15 & 3.06 & 2.95 & $0.11^{*}$ & 0.42 & days $7-84^{4}$ & 7.36 & 7.58 & 8.39 & $0.55^{*}$ & 0.40 \\
\hline \multicolumn{6}{|c|}{ Milk fat natural creaming, $\%$} & \multicolumn{6}{|c|}{ Milk rennet: curd firmness (a30) } \\
\hline day 0 & 48.29 & 49.69 & 51.61 & 2.59 & 0.66 & day 0 & 19.48 & 21.39 & 20.59 & $3.22^{*}$ & 0.91 \\
\hline day 28 & 55.72 & 62.65 & 56.82 & 2.82 & 0.19 & day 28 & 15.44 & 18.07 & 17.22 & $2.46^{*}$ & 0.74 \\
\hline day 56 & 55.56 & 57.09 & 49.64 & $3.11^{*}$ & 0.20 & day 56 & 16.62 & 13.38 & 10.13 & 2.57 & 0.23 \\
\hline day 84 & 57.92 & 58.00 & 55.00 & 3.22 & 0.76 & day 84 & 20.67 & 15.11 & 14.39 & $3.35^{\star}$ & 0.40 \\
\hline days $7-84^{4}$ & 56.23 & 59.26 & 53.80 & $2.37^{*}$ & 0.28 & days $7-84^{4}$ & 17.72 & 15.53 & 13.80 & $1.53^{*}$ & 0.35 \\
\hline
\end{tabular}

${ }^{1}$ AURA - unextracted Aurantiochytrium limacinum containing $17.04 \mathrm{~g} \mathrm{DHA} / 100 \mathrm{~g}$ (Alltech Inc., Nicholasville, KY, USA), so APC and AMC groups were supplemented with 20.1 and $25.1 \mathrm{~g}$ of DHA/cow/day, respectively; ${ }^{2}$ twelve cows from each treatment group were sampled on four occasions (day $0,28,56$ and 84 ) giving 48 milk samples per treatment group overall; ${ }^{3}$ S.E.M. - standard error of the mean; ${ }^{4}$ data analysed as repeated measures; * harmonic means

\section{Discussion}

The fatty acid composition of the milk from cows fed diets supplemented with a DHA-rich thraustochytrid Aurantiochytrium limacinum biomass
(AURA), provided in either a pelleted or meal form, was successfully altered and improved to contain significantly higher levels of DHA than the control group, in addition to improved n-6:n-3 ratio. This finding is in agreement with similar recent trials 
investigating the effect of supplementation with A. limacinum on milk fatty acid content (Moran et al., 2017b; 2018b). Both studies demonstrated a significant increase in the DHA content of milk following supplementation with AURA, with milk DHA concentrations increasing rapidly during the first weeks of supplementation until reaching their initial peaks at day 56, after which a similar level of enrichment was maintained in both studies. In the current study, a plateau between day 28 and 56 was observed for both groups, followed by a final increase to reach peak DHA concentrations by day 84. This pattern of enrichment is in contrast to the previous two studies. In the current study, on day 28 , the ambient temperature rose from approximately $22{ }^{\circ} \mathrm{C}$ to $30^{\circ} \mathrm{C}$. After this point a decrease in milk production (Figure 1) and DM intake (results not presented) was observed for all cows on the trial in the days following day 28. Decreased dry matter intake and milk production are associated with heatstress in dairy cows (Knapp and Grummer, 1991; West, 2003). The differing patterns of enrichment between this and the previous studies are likely due to the heat-stress experienced by the animals during the period directly after day 28 .

Stability to pelleting was measured by recovery of DHA (\%) from the pellet concentrate and subsequent TMR and from the meal version of the concentrate and subsequent TMR. Less DHA was recovered in the TMR of the APC diet than the AMC $\operatorname{diet}(4.7 \mathrm{vs} 5.7 \mathrm{~g} / \mathrm{kg}$, respectively). The target level of DHA intake was $25.5 \mathrm{~g}$ per cow per day. The estimated DHA intake was found to range between 19-21 g/day and 24-26 g/day for the APC and AMC diets, respectively, with only the latter meeting the expected DHA intake level. Therefore, the pelleting conditions used in this study appear to decrease the quantity of DHA recovered in the pellet concentrate. The pellet concentrate was produced from the meal concentrate so it is unlikely to be a mixing error. The lower DHA content of the APC feed was reflected in the DHA concentrations of the milk, with the APC group having a significantly lower DHA content than the AMC group on days 28, 84 and for the study overall.

The transfer efficiencies calculated based on the estimated individual intake of DHA ranged between 5 and $8 \%$. As the DHA intake was not recorded on an individual basis, the difference in transfer efficiencies between the APC and AMC groups could not be compared statistically. Other studies have previously reported a broad range of DHA transfer efficiencies from feed to milk, $1-21.6 \%$, and the efficiencies observed in this study fall within this range (Franklin et al., 1999; Chilliard et al., 2001; Boeckaert et al., 2008; Stamey et al., 2012; Moate et al., 2013; Moran et al., 2017b). The authors found no other study investigating the influence of pelleting on DHA stability in a dairy concentrate feed. However, in a previous study that investigated the effect of pelleting diets for laying hens, containing an AURA biomass, on the recovery of DHA from pellets and concomitant DHA transfer from feed to the egg yolk, the process of pelleting did not reduce the DHA content of the feed and transfer to the egg yolk was similar for birds fed pelleted or meal diets (Moran et al., 2017a). DHA, with numerous methylene-interrupted ethylenic double bonds, is sensitive to temperature with non-volatile degradation products formed, including polymers, cyclic fatty acid monomers and geometrical isomers of DHA formed above $180{ }^{\circ} \mathrm{C}$ (Fournier et al., 2006). This temperature is significantly higher than that used in this study. Therefore, further work needs to be performed on the stability and recovery of DHA in complex feed matrices particularly when provided as marine protist ingredient.

Supplementation with AURA resulted in similar milk yields for control and treatment groups. Approaching the end of the study, however, the milk yield for the supplemented groups was numerically higher. This trend was observed in a similar study following supplementation with AURA over an 84 day period, with the greatest differences in milk yield observed between days 50 and 84 (Moran et al., 2017b). Previous studies have reported a potential negative impact of algae supplementation (Boeckaert et al., 2008), as well as indicated no impact on ruminant milk yield (Bichi et al., 2013; Moate et al., 2013). The duration of supplementation, the stage of lactation, background diet, and the quantity of algae provided are likely responsible for these differences (Moran et al., 2017b).

Overall, supplementation had no effect on the fat content (\%) of the milk, however, on day 56 the AMC group had a significantly lower fat content than the CPC group (3.54 vs $4.15 ; P=0.04)$. A trend towards milk fat depression was observed for the study overall for the AMC group (3.73 vs 4.22; $P=0.087$ ). Milk fat depression as a result of supplementation with DHA-rich ingredients has been previously reported and occurs as a result of the inhibition of de novo milk FA production (Papadopoulos et al., 2002; Boeckaert et al., 2008; Moate et al., 2013; Moran et al., 2017b). The DHA intake was found to be 20.4 and $25.1 \mathrm{~g} \mathrm{DHA} /$ day for the APC and AMC groups, 
respectively, and only the $\mathrm{AMC}$ group with the higher DHA intake displayed a trend towards milk fat depression. In contrast, in a similar study, a DHA intake of $22.9 \mathrm{~g}$ DHA/day resulted in significant depression of milk fat (Moran et al., 2017b). It is likely that the discrepancies between these studies can be attributed to the heat-stress experienced by the cows in the current study, in addition to differences in the background diet of the cows in each study. The FCM however, was not affected by supplementation, which is in agreement with previous studies (Papadopoulos et al., 2002; Moran et al., 2017b; 2018b). In addition, milk protein, lactose and urea content were not affected by supplementation and were in agreement with the findings of other authors (Stamey et al., 2012; Moate et al., 2013; Moran et al., 2017b; 2018b).

The FA profile of cheese has been shown to be similar to the FA profile of the milk used to make it (Allred et al., 2006; Nudda et al., 2014; Bodkowski et al., 2016). Bodkowski et al. (2016) supplemented animal feed with synthesised CLA and n-3 rich fish oil, successfully enriching the milk with 0.16 and $0.14 \mathrm{~g} \mathrm{DHA} / 100 \mathrm{~g}$ FA after 14 and 30 days of the supplementation, respectively. The corresponding cheeses were found to have 0.09 and $0.14 \mathrm{~g}$ DHA/100 g FA maintaining similar levels of DHA as the milk used for cheese production. However, the use of PUFA enriched milk may have an impact on the cheese making properties. Avramis et al. (2003) demonstrated that milk from cows fed diets supplemented with fish meal differ in casein micelle size, protein distribution and fat globule diameter, differences that were likely to result in altered processing properties. In this study, none of the cheese making properties investigated differed significantly between the control and treatment groups. No significant differences were observed between the control and treatment groups in terms of clotting time, curd firming time and curd firmness, however further work is required to determine the effect of a greater level of supplementation on these cheese making properties. Depending on the type of cheese being produced, changes to the cheese making properties can be beneficial with faster ripening time and a more desirable texture reported for cheddar cheese produced from the milk of cows fed diets supplemented with fish meal (Avramis et al., 2003).

In the European Union, to make the nutritional claim that a food is a source of n-3 PUFA, it must contain at least $40 \mathrm{mg}$ of EPA+DHAper $100 \mathrm{~g}$ fresh weight and per $100 \mathrm{kcal}$. As such, the enriched milk from the current study would not be considered a source of n-3 PUFA. In 2018, the average price paid to milk produc- ers in the EU was approximately $€ 0.36$ (European Commision, 2018). Feeding supplementary AURA $(€ 7.00 / \mathrm{kg})$ at the same rate of the current study $(150$ $\mathrm{g} /$ day) would cost approximately $€ 1.05$ per cow per day. In our study the cost of supplementing both the APC and AMC group would be $€ 0.03$ per 1 of milk produced. Considering a nutritional claim to increase the value of the milk, it would not make financial sense to incorporate AURA in production of fresh milk. In addition, in cases where n-3 PUFA enriched milk is sold, it provides consumers with the lowest value for money when compared with other n-3 PUFA enriched foods or supplements (Watters et al., 2012). Using DHA enriched milk to produce cheese however, could be a more desirable option for dairy processors. Based on the Van Slyke yield equation (Mullan, 2008) the theoretical yield of cheese from the milk of the AP group can be calculated as follows:

cheese yield $=\frac{[(\% \text { milk fat } \times 0.93)+(\% \text { milk casein } \times 0.96)] \times 109}{100-\% \text { cheese moisture }}$

if we use: $\%$ milk fat $-3.89, \%$ milk casein -2.54 and $\%$ cheese moisture $-35,11$ of milk would produce approximately $102 \mathrm{~g}$ of cheddar cheese with a similar cheese yield observed for both the CPC and AMC groups. As the fatty acid profile of cheese is similar to the milk used to produce it (Allred et al., 2006), both the cheese of the APC and AMC groups could be expected to contain 44.7 and 63.7 $\mathrm{mg}$ of DHA/100 $\mathrm{g}$ respectively, meeting the criteria to be considered a source of n-3 PUFA, and allowing dairy farmers and processors to charge a premium for these enriched products.

\section{Conclusions}

Dietary supplementation with a docosahexaenoic acid (DHA)-rich thraustochytrid Aurantiochytrium limacinum biomass (AURA) at a dose of $150 \mathrm{~g} / \mathrm{cow} /$ day (which gives about $24 \mathrm{~g} \mathrm{DHA} / \mathrm{cow} /$ day) for 84 days resulted in the successful enrichment of milk with DHA and a nutritionally preferred decreased n-6:n-3 ratio. However the process of pelleting resulted in a lower content of DHA in feed, so better results for DHA milk content were stated for AURA supplemented in meal form. The examined level of supplementation had no effect on other various milk properties (fat, protein, lactose content) and its production yield. In addition, with no differences observed between the supplemented and control animals in terms of cheese making properties, the milk from each group would be 
similarly suitable for cheese production at this level of enrichment. However future work should investigate the influence of the DHA-rich milk obtained by AURA addition into cow diet on the maturation time and flavour profile of the cheese.

\section{References}

ADAS (Agricultural Development and Advisory Service). 1986. Condition scoring of dairy cows. Publ. 612, Agric. Dev. Advisory Serv., Min. Agric., Fisheries Food, Lion House, Alnwick, Northumberland (UK)

AOAC International, 2005. Official Methods of Analysis of AOAC International. $18^{\text {th }}$ Edition. Gaithersburg, MD (USA)

AOCS, 2017. Official Methods and Recommended Practices of the AOCS. $7^{\text {th }}$ Edition. American Oil Chemists' Society. Urban, IL (USA)

Allred S.L., Dhiman T.R., Brennand C.P., Khanal R.C., McMahon D.J., Luchini N.D., 2006. Milk and cheese from cows fed calcium salts of palm and fish oil alone or in combination with soybean products. J. Dairy Sci. 89, 234-248, https://doi.org/10.3168/jds. S0022-0302(06)72088-4

Avramis C.A., Wang H., McBride B.W., Wright T.C., Hill A.R., 2003. Physical and processing properties of milk, butter, and cheddar cheese from cows fed supplemental fish meal. J. Dairy Sci. $\quad 86, \quad 2568-2576$, https://doi.org/10.3168/jds.S00220302(03)73851-X

Bannon C.D., Craske J.D., Hilliker A.E., 1985. Analysis of fatty acid methyl esters with high accuracy and reliability. IV. Fats with fatty acids containing four or more carbon atoms. J. Am. Oil Chem. Soc. 62, 1501-1507, https://doi.org/10.1007/ BF02541903

Bichi E., Hervás G., Toral P.G., Loor J.J., Frutos P., 2013. Milk fat depression induced by dietary marine algae in dairy ewes: Persistency of milk fatty acid composition and animal performance responses. J. Dairy Sci. 96, 524-532, https://doi. org/10.3168/jds.2012-5875

Bodkowski R., Czyż K., Kupczyński R., Patkowska-Sokoła B. Nowakowski P., Wiliczkiewicz A., 2016. Lipid complex effect on fatty acid profile and chemical composition of cow milk and cheese. J. Dairy Sci. 99, 57-67, https://doi.org/10.3168/ jds.2015-9321

Boeckaert C., Vlaeminck B., Dijkstra J., Issa-Zacharia A., Van Nespen T., Van Straalen W., Fievez V., 2008. Effect of dietary starch or micro algae supplementation on rumen fermentation and milk fatty acid composition of dairy cows. J. Dairy Sci. 91, 47144727, https://doi.org/10.3168/jds.2008-1178

Caroprese M., Sevi A., Marino R., Santillo A., Tateo A., Albenzio M., 2013. Composition and textural properties of Mozzarella cheese naturally-enriched in polyunsaturated fatty acids. J. Dairy Res. 80, 276-282, https://doi.org/10.1017/S002202991300023X

Chilliard Y., Ferlay A., Doreau M., 2001. Effect of different types of forages, animal fat or marine oils in cow's diet on milk fat secretion and composition, especially conjugated linoleic acid (CLA) and polyunsaturated fatty acids. Livest. Prod. Sci. 70, 31-48, https://doi.org/10.1016/S0301-6226(01)00196-8

European Commision, 2018. EU Milk Market Observatory. https:// ec.europa.eu/agriculture/market-observatory/milk_en (accessed 1.24.19)

Fournier V., Destaillats F., Juanéda P., Dionisi F., Lambelet P., Sébédio J.-L., Berdeaux O., 2006. Thermal degradation of long-chain polyunsaturated fatty acids during deodorization of fish oil. Eur. J. Lipid Sci. Technol. 108, 33-42, https://doi. org/10.1002/ejtt.200500290
Franklin S.T., Martin K.R., Baer R.J., Schingoethe D.J., Hippen A.R., 1999. Dietary marine algae (Schizochytrium sp.) increases concentrations of conjugated linoleic, docosahexaenoic and transvaccenic acids in milk of dairy cows. J. Nutr. 129, 20482054, https://doi.org/10.1093/jn/129.11.2048

Gaines W.L., Davidson F.A., 1923. Relation between percentage fat content and yield of milk: correction of milk yield for fat content (No. 245). University of Illinois Agricultural Experiment Station. Urbana, IL (USA), pp. 577-621

Gallo A., Moschini M., Cerioli C., Masoero F., 2013. Use of principal component analysis to classify forages and predict their calculated energy content. Animal 7, 930-939, https://doi. org/10.1017/S1751731112002467

Glasser F., Doreau M., Ferlay A., Chilliard Y., 2007. Technical note: Estimation of milk fatty acid yield from milk fat data. J. Dairy Sci. 90, 2302-2304, https://doi.org/10.3168/jds.2006-870

Gómez Candela C., Bermejo López L.M., Loria Kohen V., 2011. Importance of a balanced omega 6/omega 3 ratio for the maintenance of health. Nutritional recommendations. Nutr. Hosp. 26, 323-329, https://doi.org/10.1590/S021216112011000200013

Jones E.L., Shingfield K.J., Kohen C., Jones A.K., Lupoli B., Grandison A.S., Beever D.E., Williams C.M., Calder P.C., Yaqoob P., 2005. Chemical, physical, and sensory properties of dairy products enriched with conjugated linoleic acid. J. Dairy Sci. 88, 2923-2937, https://doi.org/10.3168/jds.S00220302(05)72973-8

Knapp D.M., Grummer R.R., 1991. Response of lactating dairy cows to fat supplementation during heat stress. J. Dairy Sci. 74, 25732579, https://doi.org/10.3168/jds.S0022-0302(91)78435-X

Moate P., Williams S.R.O., Hannah M.C., Eckard R.J., Auldist M.J., Ribaux B.E., Jacobs J.L., Wales W.J., 2013. Effects of feeding algal meal high in docosahexaenoic acid on feed intake, milk production, and methane emissions in dairy cows. J. Dairy Sci. 96, 3177-3188, https://doi.org/10.3168/jds.2012-6168

Moran C.A., Currie D., Knox A., 2017a. Does pelleting affect transfer of DHA to eggs when heterotrophically-grown algae are added to layer diets? Poultry Science, 96 (E-Suppl. 1), p. 326, P295

Moran C.A., Morlacchini M., Fusconi G., 2017b. Enhancing the DHA content in milk from dairy cows by feeding ALL-G-RICH ${ }^{\mathrm{TM}}$. J. Appl. Anim. Nutr. 5, 1-9, https://doi.org/10.1017/jan.2017.9

Moran C.A., Currie D., Keegan J.D., Knox A., 2018a. Tolerance of broilers to dietary supplementation with high levels of the DHA-rich microalga, Aurantiochytrium Limacinum: effects on health and productivity. Animals 8, 180, https://doi.org/10.3390/ ani8100180

Moran C.A., Morlacchini M., Keegan J.D., Fusconi G., 2018b. The effect of dietary supplementation with Aurantiochytrium limacinum on lactating dairy cows in terms of animal health, productivity and milk composition. J. Anim. Physiol. Anim. Nutr. 102, 576-590, https://doi.org/10.1111/jpn.12827

Moran C.A., Morlacchini M., Keegan J.D., Delles, R., Fusconi G., 2018c. Effects of a DHA-rich unextracted microalgae as a dietary supplement on performance, carcass traits and meat fatty acid profile in growing-finishing pigs. J. Anim. Physiol. Anim. Nutr. 102, 1026-1038, https://doi.org/10.1111/jpn.12911

Moran C.A., Morlacchini M., Keegan J.D., Fusconi G., 2019. Increasing the omega-3 content of hen's eggs through dietary supplementation with Aurantiochytrium limacinum microalgae: effect of inclusion rate on the temporal pattern of docosahexaenoic acid enrichment, efficiency of transfer, and egg characteristics. J. Appl. Poult. Res. pfy075, https://doi. org/10.3382/japr/pfy075 
Mullan W.M.A., 2008. Determination of the theoretical yield of cheddar cheese using milk composition only and a modified version of the Van Slyke yield equation. On-line document, https:// www.dairyscience.info/newcalculators/yield-01.asp (accessed 01.23.2019)

NRC (National Research Council). 2001. Nutrient Requirements of Dairy Cattle. $7^{\text {th }}$ Revised Edition. The National Academies Press. Washington, DC (USA), https://doi.org/10.17226/9825

Nudda A., Battacone G., Neto O.B., Cannas A., Dias Francesconi A.H., Atzori A.S., Pulina G., 2014. Feeding strategies to design the fatty acid profile of sheep milk and cheese. Rev. Bras. Zootec. 43, 445-456, http://doi.org/10.1590/S151635982014000800008

O'Fallon J.V., Busboom J.R., Nelson M.L., Gaskins C.T., 2007. A direct method for fatty acid methyl ester synthesis: Application to wet meat tissues, oils, and feedstuffs. J. Anim. Sci. 85, 1511-1521, https://doi.org/10.2527/jas.2006-491

Papadopoulos G., Goulas C., Apostolaki E., Abril R., 2002. Effects of dietary supplements of algae, containing polyunsaturated fatty acids, on milk yield and the composition of milk products in dairy ewes. J. Dairy Res. 69, 357-365, https://doi. org/10.1017/S0022029902005599

Ruxton C., Reed S.C., Simpson M.J.A., Millington K.J., 2004. The health benefits of omega- 3 polyunsaturated fatty acids: a review of the evidence. J. Hum. Nutr. Diet. 17, 449-459, https:// doi.org/10.1111/j.1365-277X.2004.00552.x
Simopoulos A.P., 2008. The importance of the omega-6/omega-3 fatty acid ratio in cardiovascular disease and other chronic diseases. Exp. Biol. Med. 233, 674-688, https://doi. org/10.3181/0711-MR-311

Speroni A., Bertoni G., 1984. Creaming of milk fat: new proposals for the evaluation and the interpretation of the phenomenon (in Italian: L'affioramento del grasso del latte: nuove proposte per la valutazione e l'interpretazione del fenomen). Sci. Tecn. Latt. Casearia 35, 97-108

Stamey J.A., Shepherd D.M., de Veth M.J., Corl B.A., 2012. Use of algae or algal oil rich in n-3 fatty acids as a feed supplement for dairy cattle. J. Dairy Sci. 95, 5269-5275, https://doi. org/10.3168/jds.2012-5412

Watters C.A., Edmonds C.M., Rosner L.S, Sloss K.P., Leung P.S., 2012. A cost analysis of EPA and DHA in fish, supplements, and foods. J. Nutr. Food Sci. 2, 159, https://doi.org/10.4172/21559600.1000159

West J.W., 2003. Effects of heat-stress on production in dairy cattle. J. Dairy Sci. 86, 2131-2144, https://doi.org/10.3168/jds. S0022-0302(03)73803-X

Zymon M., Strzetelski J., Skrzyński G., 2014. Aspects of appropriate feeding of cows for production of milk enriched in the fatty acids, EPA and DHA. A review. J. Anim. Feed Sci. 23, 109-116, https://doi.org/10.22358/jafs/65698/2014 